\title{
Development of a Micromanipulator-Based Loading Device for Mechanoregulation Study of Human Mesenchymal Stem Cells in Three-Dimensional Collagen Constructs
}

\author{
Kwan Lok Au-yeung, Ph.D., ${ }^{1,2}$ Kam Yim Sze, Ph.D., ${ }^{2}$ \\ Mai Har Sham, Ph.D., ${ }^{3}$ and Barbara Pui Chan, Ph.D. ${ }^{1,2}$
}

Mechanical signal is important for regulating cellular activities, including proliferation, metabolism, matrix production, and orientation. Bioreactors with loading functions can be used to precondition cells in threedimensional (3D) constructs so as to study the cellular responses to mechanical stimulation. However, full-scale bioreactor is not always an affordable option considering the high cost of equipments and the liter-sized medium with serum and growth factor supplements. In this study, a custom-built loading system was developed by coupling a conventional camera-equipped inverted research microscope with two micromanipulators. The system was programmed to deliver either cyclic compressive loading with different frequencies or static compressive loading for 1 week to investigate the cellular responses of human mesenchymal stem cells (hMSCs) entrapped in a 3D construct consists of reconstituted collagen fibers. Cellular properties, including their alignment, cytoskeleton, and cell metabolism, and properties of matrix molecules, such as collagen fiber alignment and glycosaminoglycan deposition, were evaluated. Using a MatLab-based image analysis program, reorientation of the entrapped cells from a random distribution to a preferred alignment along the loading direction in constructs with both static and cyclic compression has been demonstrated, but no such alignment was found in the free-floating controls. Fluorescent staining on filamentous actin cytoskeleton also confirmed the finding. Nevertheless, the collagen fiber meshwork entrapping the hMSCs remained randomly distributed, and no change in cellular metabolism and glycosaminoglycans production was noted. The current study provides a simple and affordable option toward setting up a mechanoregulation facility based on existing laboratory equipments and sheds new insights on the effect of mechanical loading on the alignment of hMSCs in 3D collagen constructs.

\section{Introduction}

$\mathbf{T}$ HE IMPORTANCE OF mechanical stimulation as regulators of cellular activities and tissue function is well known for more than a decade through the promoting effects of loading and the deleterious effects of immobilization on healing of tissue injuries. ${ }^{1}$ The potential impact of mechanical stimulation on stem cells or progenitor cells such as the limb bud cells $^{2,3}$ and bone marrow-derived mesenchymal stem cells $(\mathrm{MSCs})^{4}$ has also received increasing attention recently. Most, if not all, previous mechanoregulation studies applied mechanical stimulation such as cyclic stretching ${ }^{4}$ and shear stress $^{5}$ to cells in monolayers. However, it is known that in native tissues, cells are surrounded by three-dimensional (3D) extracellular matrix, and sense mechanical signals through cell-matrix interactions. ${ }^{6}$ Hence, recent mechanoregulation studies started to utilize 3D tissue-engineered constructs. Natural materials such as type I collagen, ${ }^{7-10}$ agarose, ${ }^{3,11-17}$ alginate, ${ }^{18-21}$ and fibrin gel $^{22}$ are widely used as biomaterials in fabricating $3 \mathrm{D}$ tissue constructs.

Development of bioreactors with complicated mechanical loading functions facilitates functional tissue engineering by preconditioning the cells in $3 \mathrm{D}$ tissue constructs with appropriate growth-stimulating mechanical signals simulating that in the native tissues. ${ }^{23}$ These bioreactors can certainly be used for mechanoregulation studies to investigate the responses of cells to mechanical stimulation and the underlying mechanisms. However, these technologies are not always affordable and cost effective because of the high cost on the equipment and the consumption of liter-sized culture medium with growth factor and serum supplements. It is therefore a first objective of this study to compile a simple,

\footnotetext{
${ }^{1}$ Medical Engineering Program; ${ }^{2}$ Department of Mechanical Engineering; ${ }^{3}$ Department of Biochemistry, Li Ka Shing Faculty of Medicine, The University of Hong Kong, Hong Kong Special Administrative Region, China.
} 
affordable, and high-throughput mechanoregulation facility by coupling a conventional inverted microscope with two controllable micromanipulators.

MSCs are excellent cell sources for tissue engineering because of their relatively safe and easy accessibility from the donor, genetic stability, and the ability of self-renewal and differentiating into multiple lineages of cells. ${ }^{24,25}$ They also have the unique immunologically privileged status that can ignore the human leukocyte antigen histocompatibility bar$\operatorname{rier}^{25,26}$ and are more socially and ethically acceptable than stem cells from embryonic sources. The biological factors inducing differentiation of MSCs into multiple lineages such as osteogenic, $^{24,27}$ chondrogenic, $^{24,28,29}$ and adipogenic ${ }^{24,30}$ are well defined. Nevertheless, how does mechanical loading regulate MSC activities is not fully understood, although cyclic tensile strain or stretching ${ }^{31-36}$ and fluid shear stress 37,38 have been demonstrated to enhance osteogenic differentiation, while cyclic compressive loading, ${ }^{11,15,17-19,21,39-41}$ low intensity ultrasound, ${ }^{42,43}$ and cyclic hydrostatic pressure ${ }^{44,45}$ have been reported to enhance chondrogenic differentiation.

In our lab, a collagen-based microencapsulation technique has been developed recently to fabricate cell-collagen construct with even and random distribution of cells. This encapsulation technique overcomes the time-consuming, inefficient cell seeding procedure in traditional approach of using prefabricated porous scaffolds. The collagen gel matrix consists of randomly distributed collagen nanofibers with characteristic D-bands. ${ }^{46}$ This matrix has been shown to provide excellent matrix microenvironment to support growth of many cells, including human MSCs (hMSCs), ${ }^{46} \mathrm{fi}-$ broblasts (data not shown), chondrocytes, ${ }^{47}$ HEK293 cells, ${ }^{48,49}$ and embryonic stem cells. ${ }^{50}$ Moreover, the fibrous meshwork also provides an excellent matrix template or scaffold for cells such as chondrocytes ${ }^{47}$ and differentiating stem cells ${ }^{51}$ to remodel and then deposit their specific extracellular matrix. The cell-encapsulated collagen construct represents an excellent $3 \mathrm{D}$ experimental model for mechanoregulation studies. It is therefore the second objective of the current study to use this 3D model to investigate the effects of compression loading on hMSC activities, including cell orientation, metabolism, and extracellular matrix production. The underlying hypothesis is that mechanical loading delivered to hMSCs may affect these activities. To testify this hypothesis, 3D collagen-hMSC constructs were fabricated and exposed to daily static or cyclic compression loading, at different frequencies, in the mechanoregulation setup compiled in the current study for 1 week. The constructs were then evaluated for activities such as cell alignment, metabolism, and extracellular matrix production.

\section{Materials and Methods}

\section{Compression loading system}

A pair of micromanipulators (MP-285; Sutter Instrument, Novato, CA) was coupled to an inverted research microscope (DMIRB; Leica Microsystems, Wetzlar, Germany) equipped with heat-generating plate (Leica Microsystem). The micromanipulators were used to provide programmed cyclic movement with resolution up to $40 \mathrm{~nm}$. A pair of compression platens was modified from metal spatulas and affixed to the micromanipulators via cylindrical holders. Two-compartment Petri dish with $100 \mathrm{~mm}$ diameter (BD Biosciences, San Jose,
CA) was used as the sample holder and was affixed to the heat plate, which was adjusted to $37^{\circ} \mathrm{C}$ during compression loading. A digital camera (CoolSNAP ES; Roper Scientific, Göttingen, Lower Saxony, Germany) coupled to the microscope was used to record the movement of the compression platens and the deformation of the samples during compression at a rate of 200 frames per minute (Fig. 1). A maximum of two loading conditions can be tested at the same time when the two micromanipulators were programmed separately to deliver different loading conditions. A maximum of four samples per loading condition can be loaded at the same time. Discshaped samples subjected to the same loading condition were placed between the partition walls of the two-compartment Petri dish. The long axis of the disc-shaped samples was parallel to the partition wall of the Petri dish, while the short axis was along the compression loading axis. The Petri dish was filled with $7 \mathrm{~mL}$ culture medium, which was covered by a thin layer of silicon oil to prevent contamination. The micromanipulators were programmed to deliver cyclic movement so that the compression platens moved toward and away from the wall of two-compartment Petri dish to compress the constructs (Fig. 1B).

\section{Culture of hMSCs}

hMSCs from human bone marrow were kindly provided by Dr. G.C.F. Chan from Department of Paediatrics \& Adolescent Medicine of the same institution. All procedures were approved by the Combined Clinical Ethical Committee of the University of Hong Kong and Hong Kong West Cluster Hospitals of Hospital Authority. hMSCs were isolated and cultured as previously reported. ${ }^{52}$ In brief, hMSCs were cultured in Dulbecco's modified Eagle's medium-low glucose (Gibco, Grand Island, NY) supplemented with 10\% fetal bovine serum (Gibco), $100 \mathrm{U} / \mathrm{mL}$ penicillin (Gibco), $100 \mu \mathrm{g} / \mathrm{mL}$ streptomycin (Gibco), and $2 \mathrm{mM}$ L-glutamine (Gibco), and incubated in a humidified condition with $5 \% \mathrm{CO}_{2}$ at $37^{\circ} \mathrm{C}$. Culture medium was changed every 3 days. Cells at $80-90 \%$ confluence were trypsinized using $0.05 \%$ trypsin-ethylenediaminetetraacetic acid (Gibco) and subcultured by replating the cells at a density of $2 \times 10^{5}$ cells per $75 \mathrm{~cm}^{2}$ flask. Cells at passage 6 were used for subsequent construct preparation. The immunophenotype, self-renewal capacity, and multiple differentiating potential of the isolated and cultured hMSCs were verified in our previous study. ${ }^{46}$

\section{Preparation of disc-shaped collagen-hMSC constructs}

A custom-made cylindrical container with nonadhesive surface was used to cast the constructs. Rat-tail collagen type I solution (BD Biosciences, San Jose, CA) was neutralized with sodium hydroxide (Sigma-Aldrich, St. Louis, MO) before mixing with single-cell suspension of hMSC in culture medium. The cell collagen mixture was diluted by culture medium to a final cell density of $1 \times 10^{6}$ cells $/ \mathrm{mL}$ and a final collagen concentration of $2 \mathrm{mg} / \mathrm{mL}$. The mixture was kept in an ice-bath throughout the preparation to prevent collagen gelation. An aliquot of $100 \mu \mathrm{L}$ of the cell-collagen mixture solution was pipetted into the container and incubated at $37^{\circ} \mathrm{C}$ for 1 hour for gelation. The cell-entrapped collagen gel was detached from the container and transferred to a 24-well plate (Iwaki, Tokyo, Japan) with its bottom covered by a parafilm to prevent migration of hMSCs from the construct 


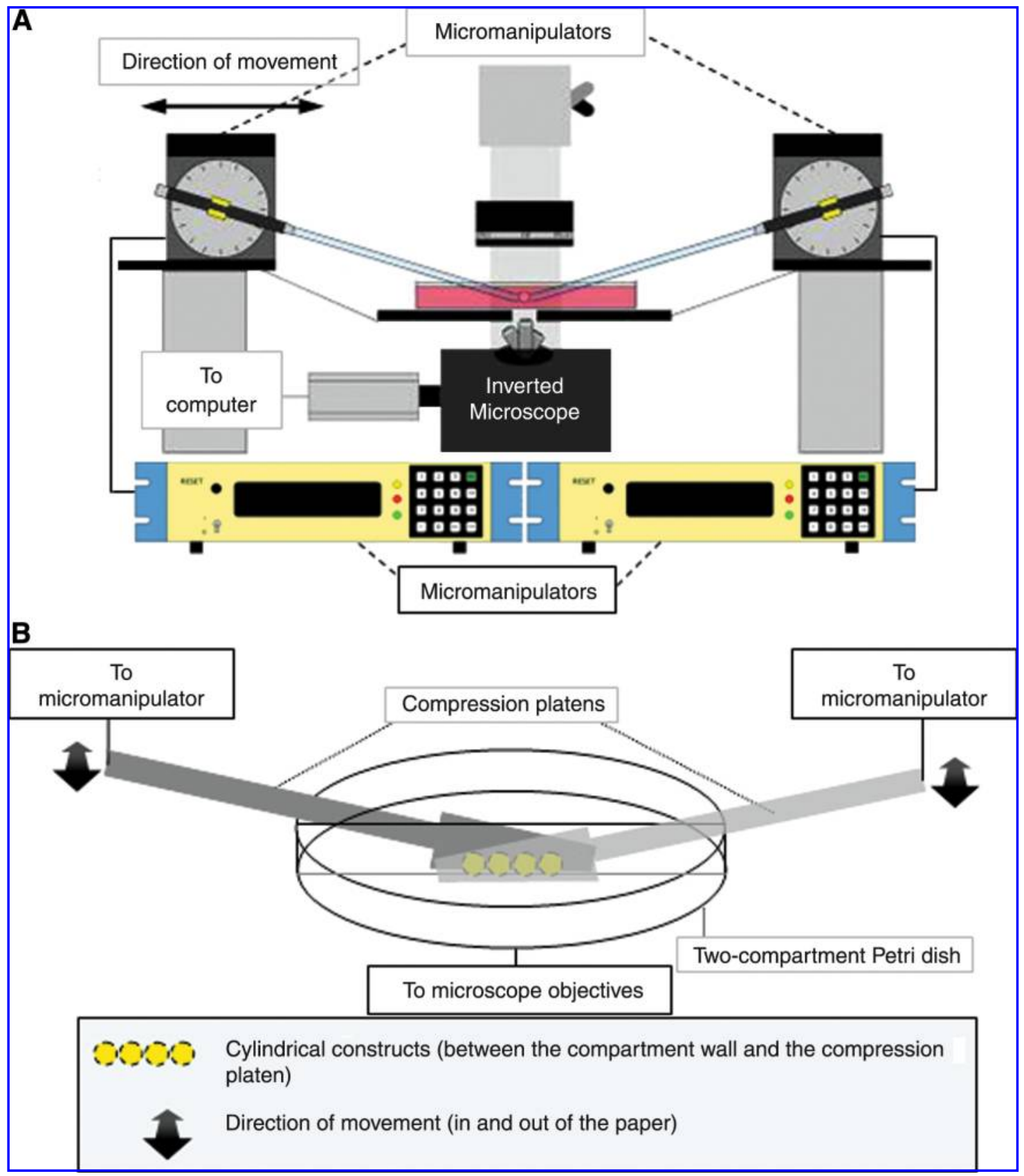

FIG. 1. Schematic diagram showing the loading device. (A) Coupling of the micromanipulators and control boxes with inverted microscope. (B) Sample chamber. Color images available online at www.liebertonline.com/ten.

to the culture well. The construct was then cultured and allowed to contract for 4 days before compression.

\section{Loading regime}

The height of the disc-shaped construct before compression ( $h$, the undeformed height) was measured under the microscope. In the static compression control (loaded at $0 \mathrm{~Hz}$ ), the construct was subjected to a static compression to $0.9 \mathrm{~h}$ deformed height. In the cyclic compression group, the construct was first subjected to a static compression to $0.9 \mathrm{~h}$ deformed height and then further deformed in a cyclic manner such that its deformed height varied between $0.8 \mathrm{~h}$ and $0.9 h$ at $1,0.5$, and $0.1 \mathrm{~Hz}$. Micromanipulators were pro- grammed with appropriate traveling distance and frequency. The loading regime was looped until it was interrupted by the user. The constructs were loaded 1 hour per day for 7 consecutive days with daily medium change. All samples were cultured in 24-well plate at $37^{\circ} \mathrm{C}$ in $5 \% \mathrm{CO}_{2}$ incubator.

\section{Histological evaluations}

The constructs were fixed in $4 \%$ paraformaldehyde for overnight at $4{ }^{\circ} \mathrm{C}$ and embedded for preparation of $10-\mu \mathrm{m}-$ thick paraffin sections at the cross sections of the disc-shaped constructs. Turning of samples was prevented by carefully sectioning and mounting the sections with the same direction. Even though the sections were accidentally turned 
upside down, the loading direction was easily identified by differentiating the short and the long axes. Moreover, the outcome measure is how far the cell alignment is deviating from the vertical compression loading axis $\left(90^{\circ}\right)$ from either left or right $\left( \pm N^{\circ}\right.$ away from $\left.90^{\circ}\right)$; as a result, even though the sections were accidentally turned from left to right during mounting, the deviation would change from +ve to - ve sign. This would not affect the results at all as the signs would be ignored during the subsequent data analysis for peak angle. Hematoxylin and eosin staining was performed to reveal the morphology of the entrapped cells in collagen constructs, while hematoxylin staining was used for subsequent image analysis for cell alignment.

\section{Fast Fourier image analysis}

Images of the sectioned samples were captured by an inverted microscope (Eclipse TE2000-U; Nikon, Tokyo, Japan) and rotated such that the short axis of the samples was parallel to the compression loading axis. The edge effect of the stained sections was removed by cropping the central $650 \times 650$ square-pixel-sized region of the images, which covered $32-52 \%$ of total pixel area of the sample for all constructs. Fast Fourier Transform (FFT) was previously employed as a method to quantify the alignment of collagen fiber $^{53}$ and cells. ${ }^{54}$ An ad hoc Matlab program based on the algorithm of FFT technique was developed to quantify the alignment of cells in the edited images. In brief, the colored image was converted into grayscale where the information was treated as a matrix array by the program. Welch windowing was applied to remove the edge effect. FFT was carried out to transform the matrix into spatial frequency. Summation of the frequency components of each degree ranging from $0^{\circ}$ to $179^{\circ}$, respectively, would give a power spectrum showing the intensity of the signals versus angle in degrees. The power spectrum was then analyzed for preferred cell alignment by measuring the peak angle, which was the angle with maximum intensity and the presence of dominant peak, which statistically compared the intensity signal above and below the median in the power spectrum. Since the intensity of the power spectrum was affected by factors like the intensity of staining, it could not be directly used to represent the number of cells in any particular angle, yet it could tell the angle at which most cells aligned.

\section{Scanning electron microscopy}

The constructs were fixed with $2 \%$ glutaraldehyde (SigmaAldrich) for 3 hours at room temperature and dehydrated by a gradient of ethanol from $50 \%$ to $100 \%$, followed by critical point drying in a critical point dryer (Bal-Tec, Balzers, Switzerland, CPD 030). The dried constructs were fractured to expose its cross sections. The constructs were mounted to the metal stub with carbon cement to expose the cross sections, followed by gold-palladium coating by sputter coater (Bal-Tec SCD 005). Images were taken by a field emission scanning electron microscope (Leo 1530, Carl Zeiss SMT, Peabody, MA).

\section{Phalloidin staining for cytoskeleton}

F-actin filament of hMSCs was stained with rhodamine phalloidin (Invitrogen, Carlsbad, CA) for fluorescent mi- croscopy examination. Briefly, the constructs were fixed with $2 \%$ paraformaldehyde, and then they were preincubated with $1 \%$ bovine serum albumin (Sigma-Aldrich) to reduce nonspecific background staining. They were stained with $165 \mathrm{nM}$ rhodamine phalloidin for overnight at $4^{\circ} \mathrm{C}$. Images of the sectioned samples were obtained by fluorescent microscopy.

\section{Glycosaminoglycan quantification}

Glycosaminoglycan (GAG) was quantified by dimethylmethylene blue (DMMB) assay. ${ }^{55}$ Briefly, the constructs were digested by papain solution for 6 hours. About 1,9-DMMB (Sigma-Aldrich) solution was added to the digested samples with regular agitation. GAG-DMMB complex formed was dissociated with a dissociation reagent consisted of guanidine hydrochloride (International Laboratory, San Bruno, CA), sodium acetate trihydrate (Sigma-Aldrich), and isopropanol (BDH, Dorset, United Kingdom). The resulting solution was transferred to a 96-well plate and absorbance for optical density measurement at $656 \mathrm{~nm}$ using a microplate reader (Safire 2).

\section{Cell metabolism quantification}

The metabolic activity of cells entrapped in the collagen construct was assessed by MTT assay (thiazolyl blue tetrazolium bromide) (Sigma-Aldrich) assay. ${ }^{56-58}$ Briefly, the constructs were incubated in $5 \mathrm{mg} / \mathrm{mL}$ MTT solution for 4 hours in a humidified condition and $5 \% \mathrm{CO}_{2}$ at $37^{\circ} \mathrm{C}$. About $0.04 \mathrm{~N}$ acidic isopropanol was used to dissolve and extract the insoluble formazan. The resulting solutions were transferred to a 96-well plate, and absorbance at $540 \mathrm{~nm}$ was measured using a microplate reader (Safire 2).

\section{Statistical analysis}

Dominance of the peaks of the power spectrums was analyzed by comparing the intensities above and below the sample median using nonparametric Wilcoxon Signed Rank Test. Differences in the amounts of GAG and relative intensities of MTT assay in different treatment groups (1, 0.5, and $0.1 \mathrm{~Hz}$ cyclically loaded groups, statically preloaded group, and the free-floating control group) were analyzed using nonparametric Kruskal-Wallis test. Statistical tests were performed using (SPSS 16.0, Chicago, IL)T and a significance level was set at 0.05 .

\section{Results}

\section{A maximum throughput of eight samples can be loaded simultaneously}

Disc-shaped hMSC-collagen constructs of approximately $1.9 \pm 0.1 \mathrm{~mm}$ in diameter and $1.2 \pm 0.1 \mathrm{~mm}$ in height were fabricated. A maximum throughput of eight samples can be loaded at the same time (Fig. 2) when both micromanipulators were programmed for the same loading condition.

\section{Morphology and distribution of cells in the collagen constructs}

As shown in Figure 3, hMSCs randomly distributed within the constructs although small amount of cells aggregated at the peripheral region in some constructs. After removing the 


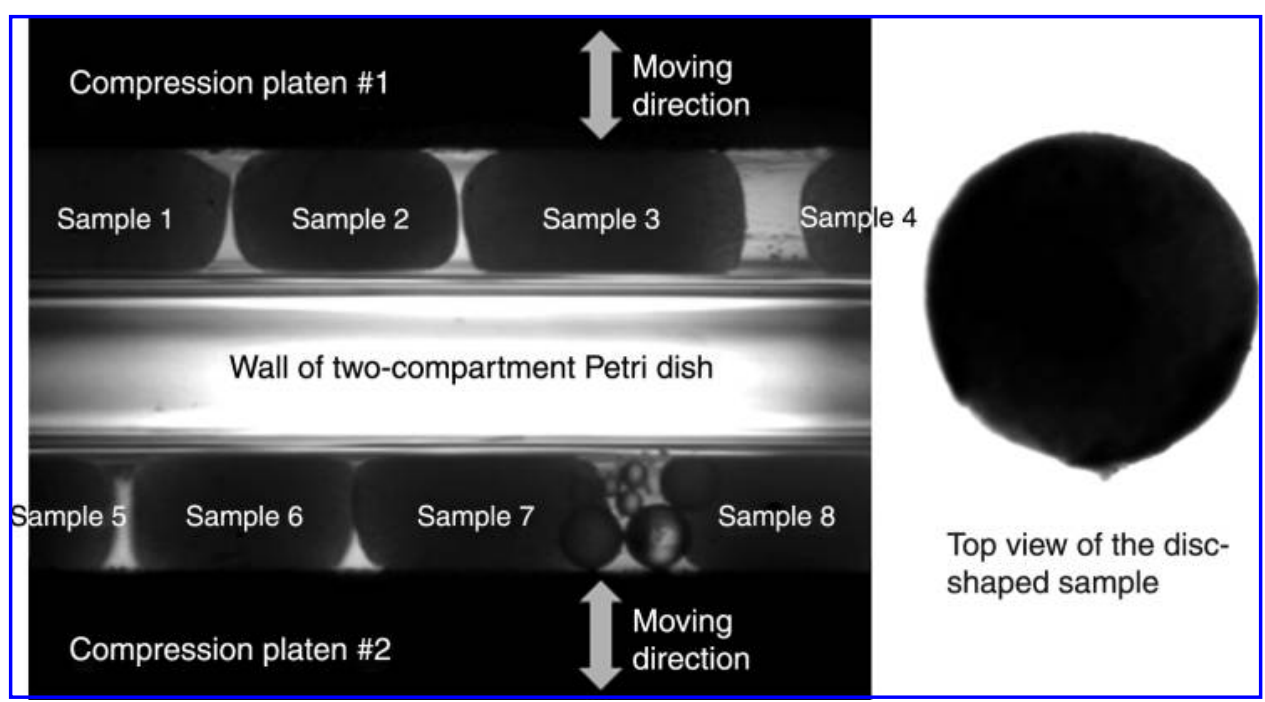

FIG. 2. Phase contrast microscopy showing the sample chamber and the samples during compression.

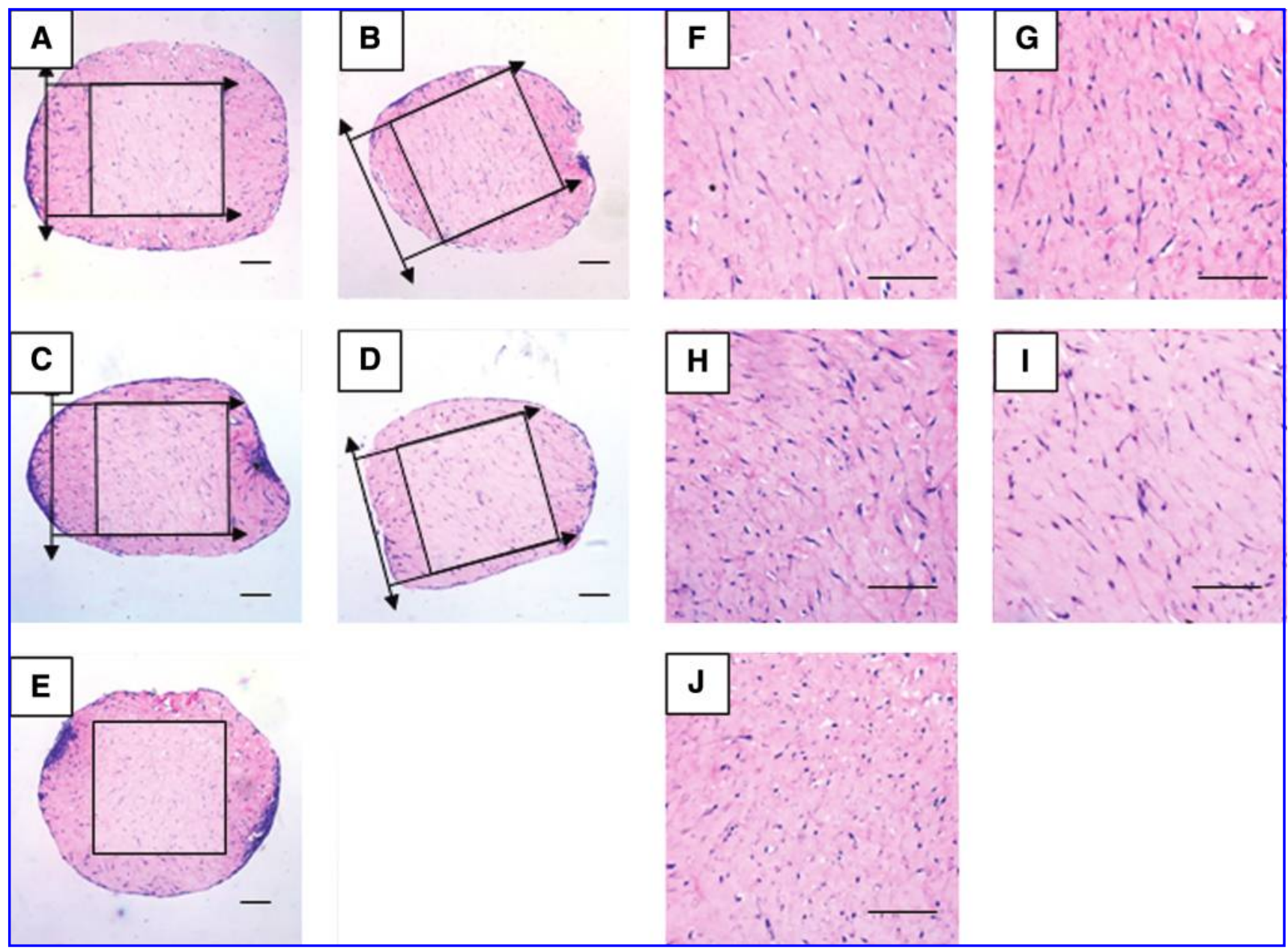

FIG. 3. Hematoxylin and eosin staining showing the cross sections of the constructs. (A-E) Images of the constructs before removing the edge effects (scale bar $=100 \mu \mathrm{m}$ ). ( $\mathbf{F}-\mathbf{J})$ Magnified images of the constructs after removing the edge effects (scale bar $=100 \mu \mathrm{m})$. Cyclic loading at $(\mathbf{A}, \mathbf{F}) 1 \mathrm{~Hz},(\mathbf{B}, \mathbf{G}) 0.5 \mathrm{~Hz}$, and $(\mathbf{C}, \mathbf{H}) 0.1 \mathrm{~Hz} ;(\mathbf{D}, \mathbf{I})$ static loading; (E, J) free-floating control. Color images available online at www.liebertonline.com/ten. 
edge effect (Fig. 3A-E), both the cyclically loaded (Fig. 3F-H) and the statically loaded (Fig. 3I) groups showed preferred cell alignment parallel to the direction of the compressive loading (Y-axis of Fig. 3F-I). No difference in cell alignment was observed among different loading frequencies. However, the free-floating control showed no observable alignment of cells in any preferred direction (Fig. 3J). Moreover, elongation of the cell body and extension of cell processes (Fig. 3F-I) were observed in all loaded groups, while round cells were found in the free-floating group (Fig. 3J).

\section{Quantitative analysis of cell alignment}

Images were first undergone FFT (Fig. 4) to generate power spectra (Fig. 5), which were then analyzed for both the peak angle and the presence of dominant peaks (Fig. 6). Specifically, Figure 4A showa a representative hematoxylin-stained image, which was converted into grayscale (Fig. 4B) before filtering by Welch Window to remove the edge effect (Fig. 4C). Figure $4 \mathrm{D}$ showed the frequency domain after FFT and the output of the program was in the form of a power spectrum of intensity against angle (Fig. 5). In Figure 5, the angle $90^{\circ}$ represented the direction of compressive loading, while the angle $0^{\circ}$ represented the horizontal axis of the image perpendicular to the compression loading axis. Peak angle was defined as the angle at which the intensity was maximum, and theoretically, the angle at which most cells aligned. Peak angle ranged from $0^{\circ}$ to $90^{\circ}$ rather than $0^{\circ}$ to $180^{\circ}$ was counted because the section might be vertically or horizontally inverted during sample preparation. Deviation of the peak angle from $90^{\circ}$, which is the direction of the compressive loading showed the direction of the cell alignment, if any. The upper panel of Figure 6 shows the dot plot of the peak angles measured from the power spectra versus their respective net change in intensity. Most if not all cyclically loaded samples clustered between $80^{\circ}$ and $90^{\circ}$, while for the statically loaded samples, the peak angles deviated within a narrow range of $20^{\circ}$ from the compression loading axis at $90^{\circ}$. However, for samples in the free-floating control group, peak angles were found to range from $4^{\circ}$ to $72^{\circ}$ without obvious clusters, suggesting randomness or arbitrariness. The lower panel of Figure 6 tabulates the peak angles of the power spectra from different groups and confirms that the mean angles ( \pm standard deviations) at which most cells in the cyclically loaded groups aligned were $85 \pm 4^{\circ}$, $87 \pm 2^{\circ}$, and $81 \pm 6^{\circ}$ for $1,0.5$, and $0.1 \mathrm{~Hz}$, respectively, while those in the statically loaded group was $75 \pm 5^{\circ}$. However, the mean peak angle for the free-floating control group was $36 \pm 24^{\circ}$. The dot plot also showed higher relative intensities in the cyclic compression groups comparing with that of the freefloating control group, implying the dominance of peaks. The lower panel of Figure 6 also showa the statistical analysis results on the presence of dominant peak in different groups. In the compression loaded groups, the majority of samples showed significant results in the presence of dominant peaks $(p<0.05)$ but in the free-floating control group, more than half of the peaks were not dominant.

\section{Fluorescent staining for cytoskeleton confirmed the alignment}

Cytoskeleton F-actin filament has been used as an intracellular fluorescent staining for MSCs in collagen constructs. The fluorescent signals also showed elongated morphology of the cells and obvious alignment along the compression
FIG. 4. Fast Fourier Transform (FFT) image analysis for cell alignment. (A) Hematoxylin-stained image. (B) Grayscale image. (C) Welch windowed image. (D) Frequency domain of the image after FFT.

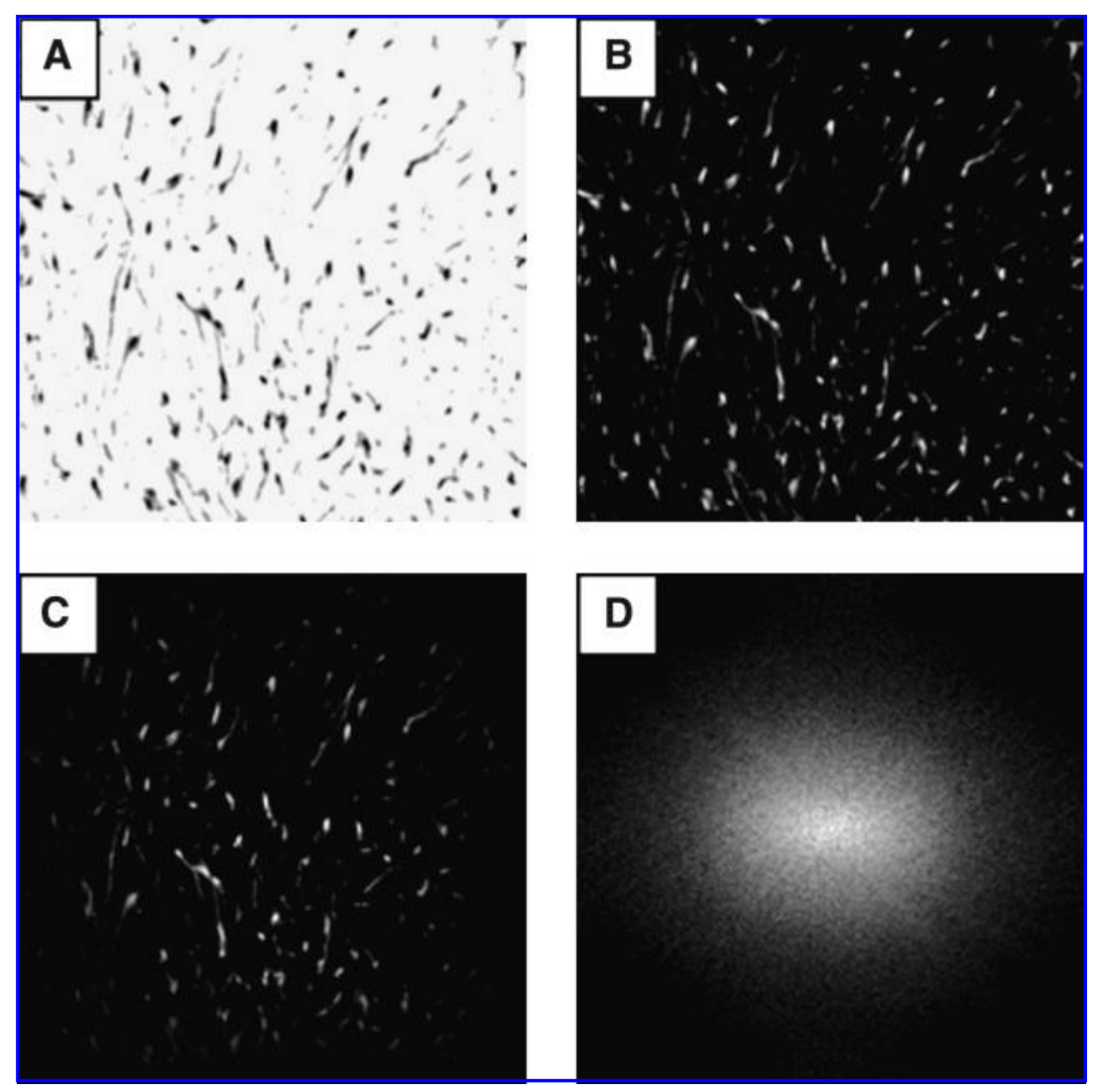




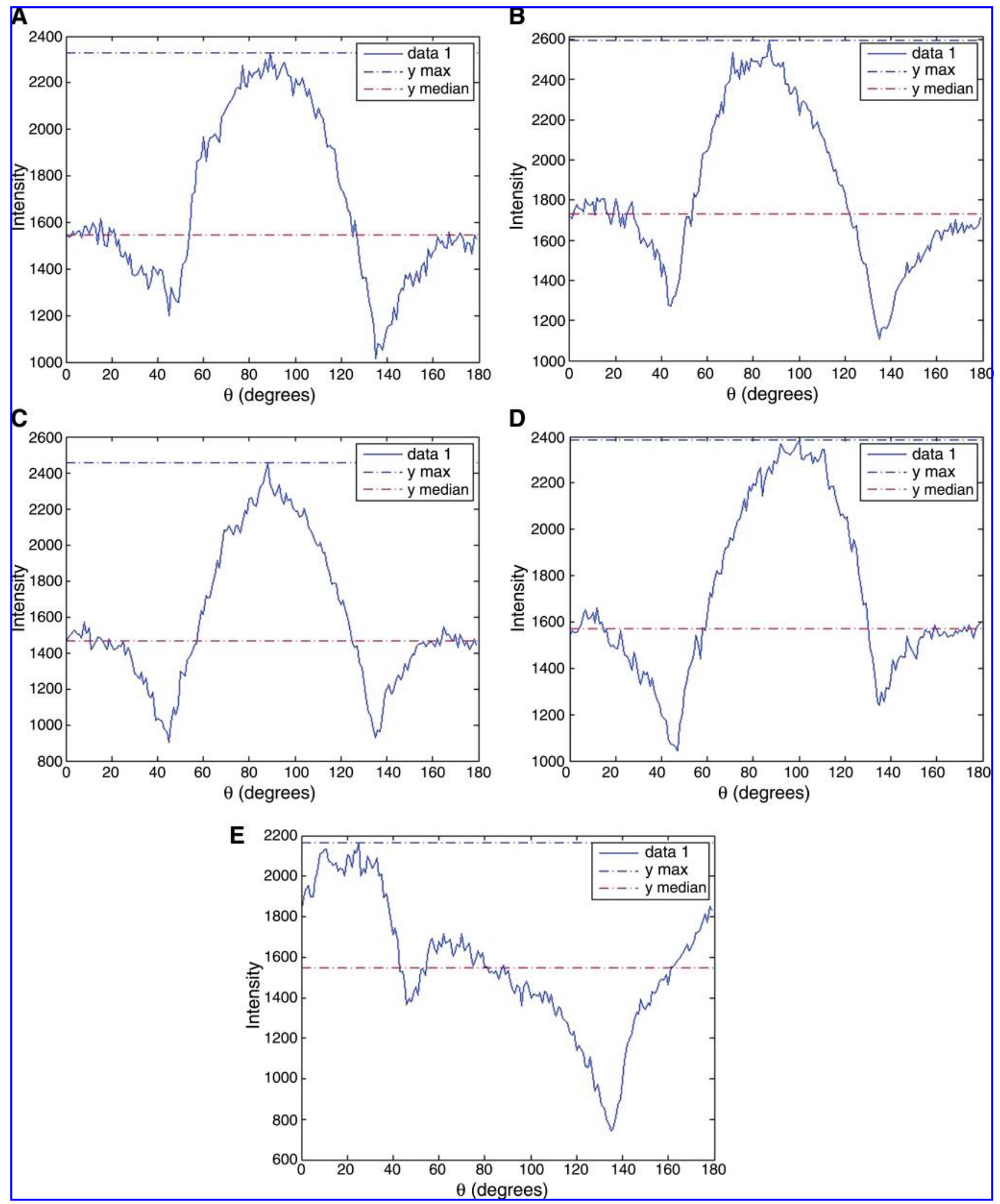

FIG. 5. Representative power spectra of FFT-processed images. (A) $1 \mathrm{~Hz},(\mathbf{B}) 0.5 \mathrm{~Hz},(\mathbf{C}) 0.1 \mathrm{~Hz}$, (D) static, and (E) freefloating. Color images available online at www.liebertonline.com/ten. 
FIG. 6. Analysis for peak angles at which most cells aligned in different groups. Upper panel: Dot plot showing the normalized peak intensities (net difference between maximum intensities and medians) against peak angles. Lower panel: Tabulated peak angles and their means and standard deviations in different treatment groups $(n=6-9)$. Color images available online at www.liebertonline.com/ten.

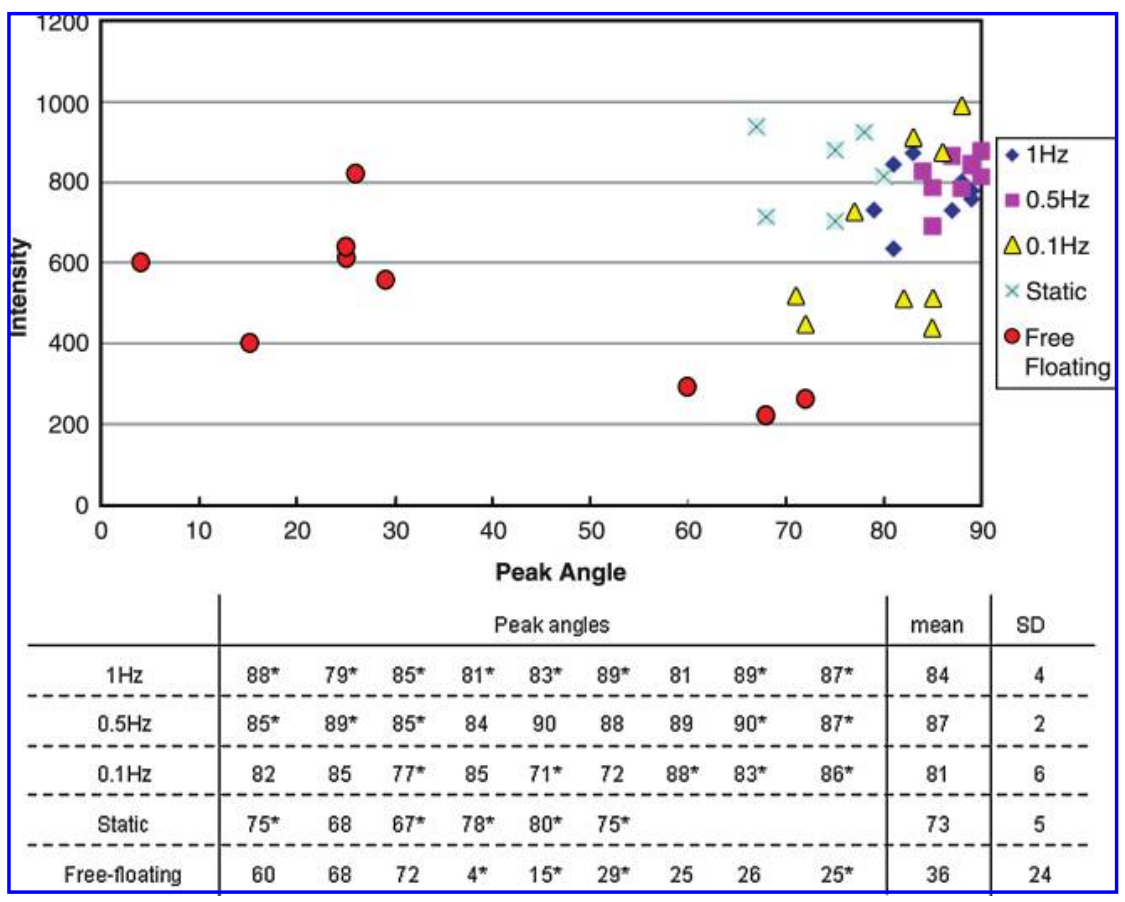

loading axis, which was predetermined under the phase contrast image of the same section, in all compression loaded groups (Fig. 7A-D), while the free-floating control group showed no elongated morphology and alignment of cells (Fig. 7E).

\section{Randomly distributed collagen fiber meshwork}

The ultrafine microstructures of the collagen constructs entrapping the hMSCs showed meshwork of nano-sized collagen fibers (Fig. 8). In all cyclic compression loaded
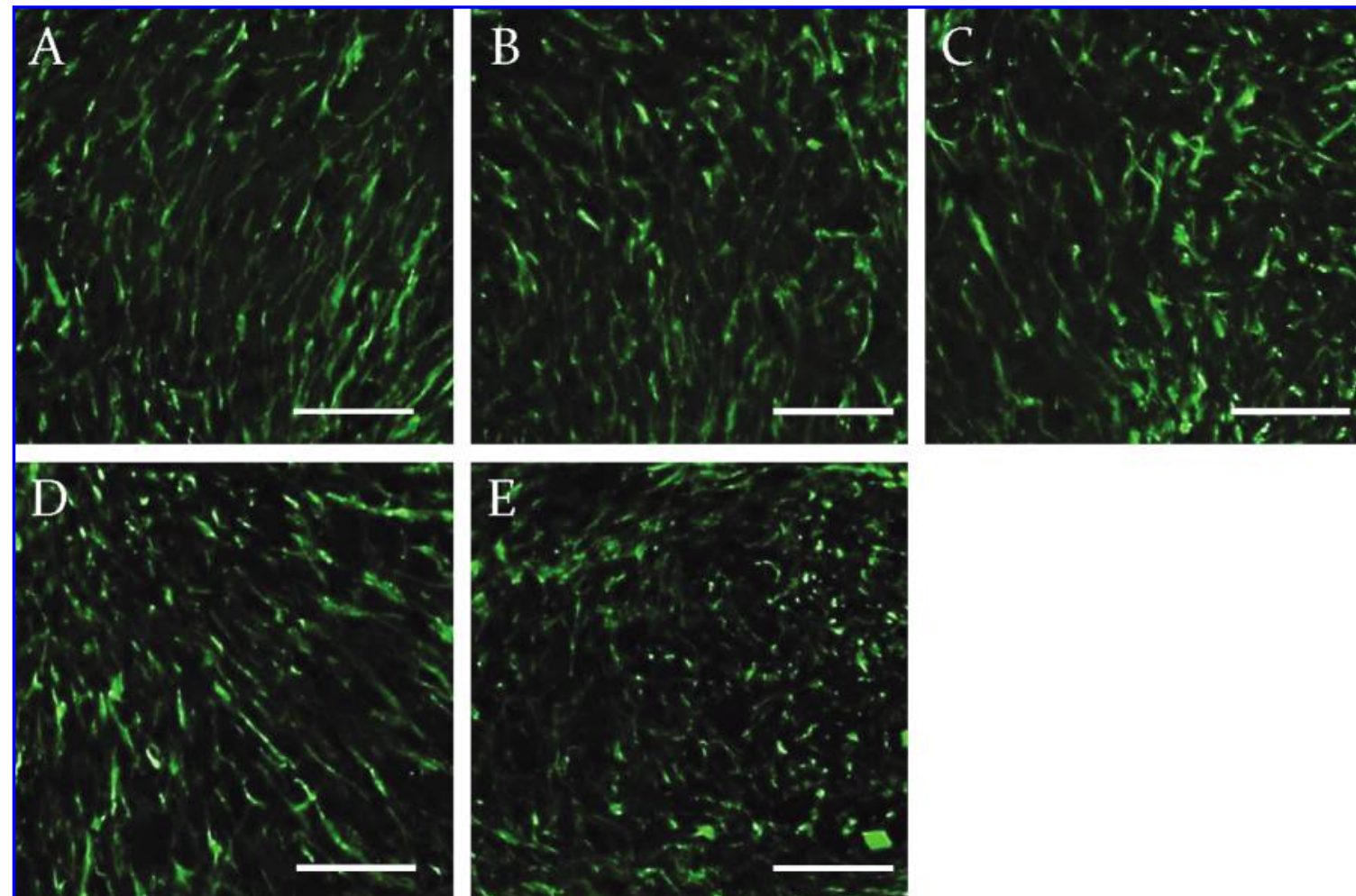

FIG. 7. Confocal laser scanning microscopy showing rhodamine phalloidin staining for F-actin filaments in constructs. (A) $1 \mathrm{~Hz},(\mathbf{B}) 0.5 \mathrm{~Hz},(\mathbf{C}) 0.1 \mathrm{~Hz},(\mathbf{D})$ static loading, and (E) free-floating control. Scale bar $=100 \mu \mathrm{m}$. Color images available online at www.liebertonline.com/ten. 


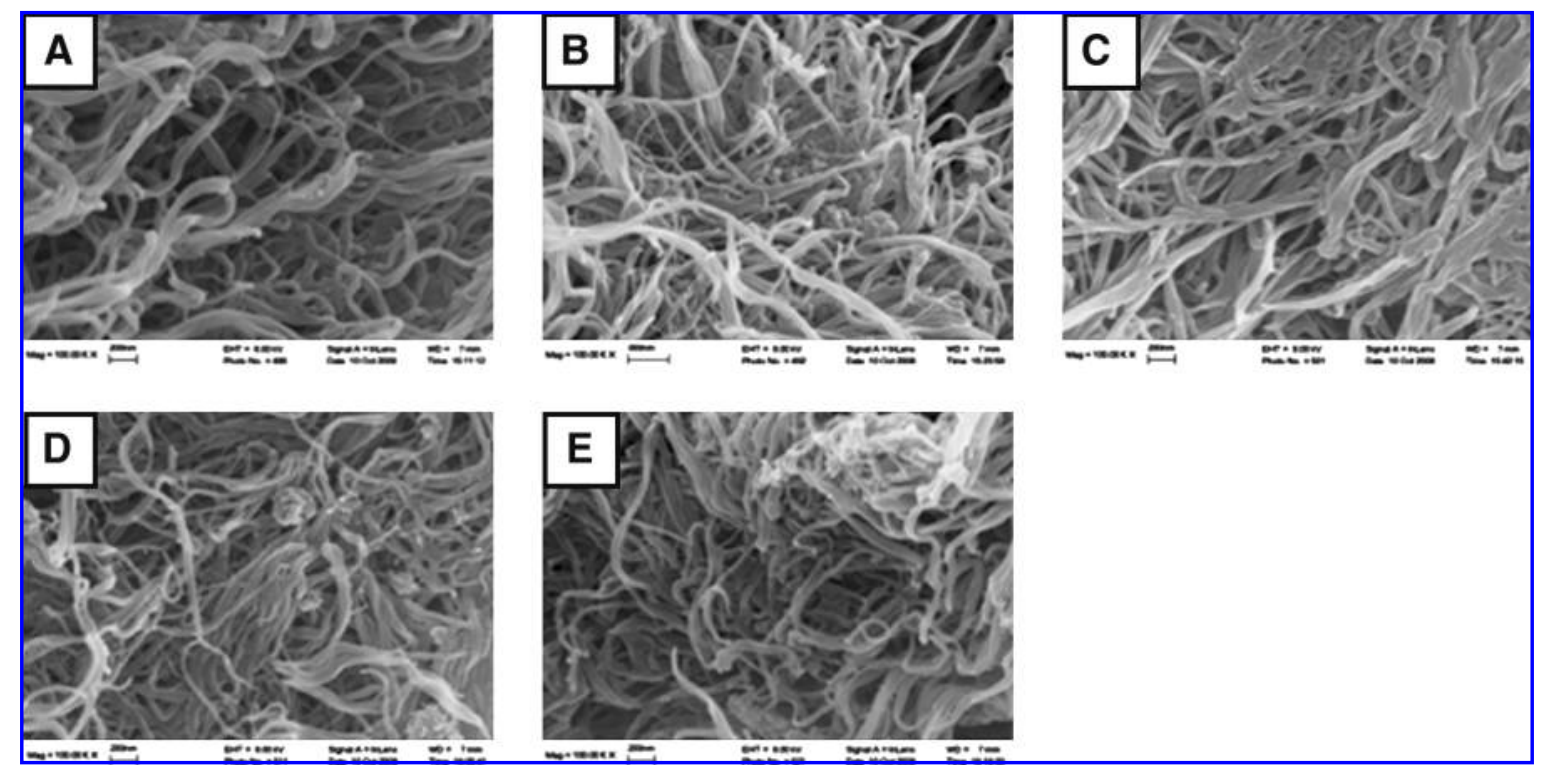

FIG. 8. Scanning electron microscopy images showing the random orientation of collagen fibrils in contents of different treatment groups. (A) $1 \mathrm{~Hz},(\mathbf{B}) 0.5 \mathrm{~Hz},(\mathbf{C}) 0.1 \mathrm{~Hz},(\mathbf{D})$ static loading, and (E) free-floating control.

groups (Fig. 8A-C), the static compression loaded group (Fig. 8D), and the free-floating control group (Fig. 8E), collagen fibers were found randomly distributed throughout the samples without any preferred alignment.

\section{Unaltered cellular metabolism}

From the result of MTT assay (Fig. 9), the metabolism of cells was not altered by mechanical compressive loading. All groups showed similar level of cellular metabolism without significant difference $(p>0.05)$. The optical density values were normalized with the free-floating control.

\section{Unaltered GAG production}

Figure 10 shows that the amount of GAG content in different treatment groups was similar, and nonparametric Kruskal-Wallis test shows that no statistically significant difference was found among different groups $(p>0.05)$.

\section{Discussion}

A micromanipulator-based mechanical loading system capable of delivering cyclic compressive loading to multiple samples simultaneously was developed. We demonstrated that hMSCs entrapped in a collagen fiber meshwork responded to compressive loading by reorienting themselves to a preferred alignment along the axis of compressive loading. This study provides a simple and affordable option for cellular mechanoregulation studies and can be used in screening and optimizing parameters during scaffold and loading regime design.

\section{Favorable features and limitations of the current mechanoregulation setup}

With this micromanipulator-based loading system, smaller constructs can be used, requiring less scaffold materials and cells for mechanoregulation studies. As a result, only several milliliters of culture medium was sufficient for

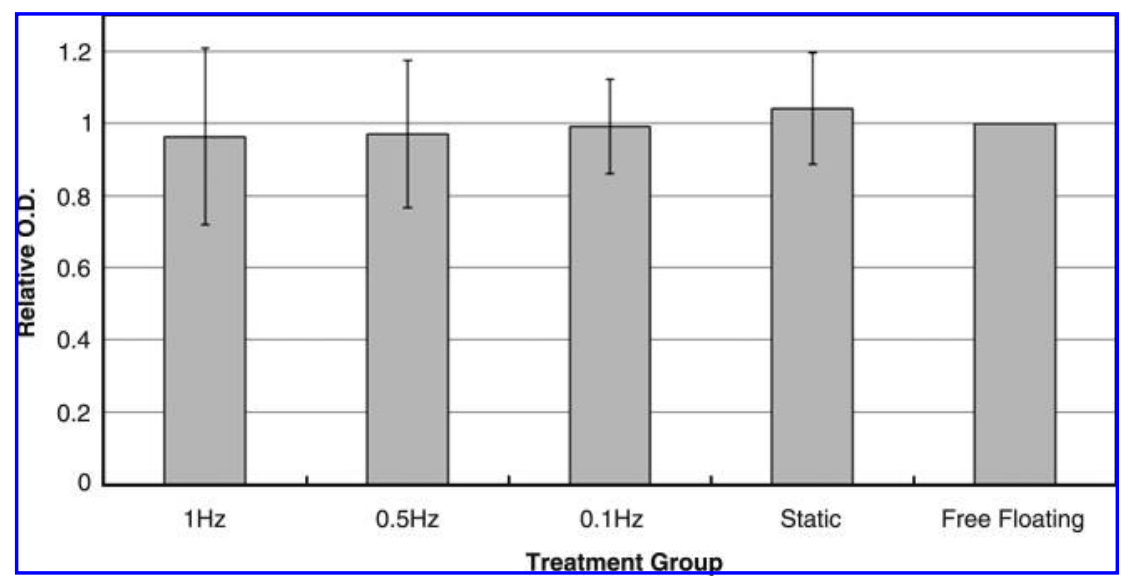

FIG. 9. Bar chart showing the normalized absorbance at optical density 540 of the MTT assay in different treatment groups $(n=4)$. 
FIG. 10. Bar chart showing the amount of glycosaminoglycan (GAG) content in constructs of different treatment groups $(n=5$ to 6$)$.

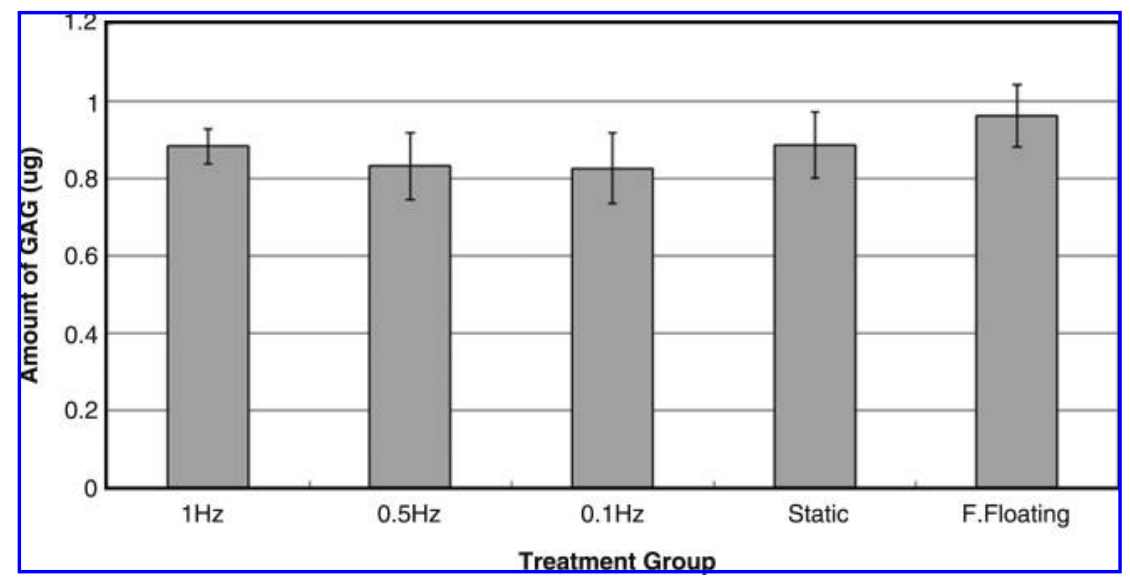

mechanical loading of as many as eight samples in contrast to $100 \mathrm{~mL}$ or liter-sized culture medium for a single sample in full size bioreactors, making the setup a very affordable and efficient system for mechanoregulation studies. Moreover, the loading process and hence the construct deformation can be viewed in real time. This feature also enables investigation of real-time cellular response to mechanical loading if a confocal laser scanning microscope is coupled with the setup. Further, this system can be easily modified to provide other modes of mechanical loading such as tensile loading (data not shown) and to perform other functions such as measuring the elastic modulus of single cells and soft hydrogel constructs. ${ }^{59}$ However, this system does have several limitations. First, it is currently a displacementcontrolled system and cannot provide the force-control option without modifications. Second, loading frequency higher than $2 \mathrm{~Hz}$ cannot be achieved due to the limitation of the micromanipulators used in this system. Finally, the waveforms of loading are not exactly the same for different loading frequencies due to the limitation of the micromanipulators.

\section{Significance of cell alignment in tissue engineering and differential response of cell alignment in two-dimensional and 3D culture models}

Cell alignment is important for the proper functioning of native tissues such as ligament, ${ }^{60,61}$ tendon, ${ }^{62,63}$ and muscle. ${ }^{64,65}$ The mechanical property of tendon and ligament is associated with the collagen matrix organization, which is closely related to the alignment of cells ${ }^{63,66}$ and is mediated through cytoskeleton such as actin filaments. ${ }^{62}$ The proper transduction of electrical signals of heart muscle has been facilitated by the alignment of cardiomyocytes, which gives the anisotropic structure of the heart tissue. ${ }^{65,67}$ Moreover, the significance of cell alignment has also been demonstrated in engineered tissues with better functional properties. In particular, cell alignment comparable to that in the normal tendon has been shown related to the improved mechanical properties of repaired patellar tendon using MSC-seeded collagen matrix. ${ }^{68,69}$ As a result, incorporating cell alignment into the construct design is important to assure better functional properties of the engineered tissues. A number of physical factors, including electrical stimulus, ${ }^{70-74}$ mechanical loading such as tensile stretching and interstitial fluid flow, ${ }^{7,54,70-72,74-80}$ and surface topology such as micro- grooves $^{66,81-91}$ and electrospun fibers, ${ }^{92,93}$ were found to induce cell alignment. In most previous studies on the effect of mechanical loading on cell alignment, two-dimensional (2D) deformable culture substrates such as a fibronectin-coated silicon membrane have been used. In these studies, cells such as fibroblasts ${ }^{73,74}$ and endothelial cells ${ }^{71}$ have been shown to orient themselves away from or perpendicular to the tensional loading axis. This has been described as the "avoidance response to stretch." 73 However, the cellular responses to loading become very different when the cells are embedded in a hydrogel material, therefore giving a 3D tissue-like construct. Specifically, when the cell-embedded 3D structures are mechanically stretched, cells align along the axis of stretching no matter whether they are fibroblasts ${ }^{70,94}$ or bone marrow MSCs. ${ }^{95}$ This big difference in cellular alignment may be due to the differential pattern of cell-matrix interaction in 2D and 3D experimental models. For example, cells in 3D matrix express a different pattern of cell-matrix interacting molecules such as integrin comparing with that in 2D configuration. ${ }^{6}$ Moreover, the presence of matrix may serve as an important function to transfer load to other parts of the matrix as well as to cells and hence the mechanical compliance or stiffness of the matrix may also contribute to the load transfer to cells in $3 \mathrm{D}$ constructs. In fact, the intrinsic mechanical properties of matrix did affect cellular activities. ${ }^{96,97}$ Further, cells cultured on $2 \mathrm{D}$ substrates have more freedom to migrate and move particularly when they are in subconfluence, ${ }^{71,73,74}$ but cells embedded in 3D extracellular matrix have more constraints to movement. All in all, cells in 3D matrix interact with the matrix, sense the force applied, and migrate in a different manner comparing with that on 2D substrates and therefore may result differently in cell alignment. In this study, we are the first to demonstrate that compressive loading, both static and cyclic, induced the alignment of hMSCs in a direction parallel to the axis of loading in a $3 \mathrm{D}$ collagen matrix. Although the exact mechanism of the cellular response to loading has not be fully delineated, this has been suggested as a phenomenon where cells under mechanical loading tend to orient themselves in a way that the strain applied to them was reduced to the minimum level. ${ }^{70}$ The same explanation may also be applicable in the current study as the strain applied to hMSCs in a collagen gel under compressive loading would also be minimal if the cells are in alignment with the axis of loading (Supplemental Fig. S1, available online at www .liebertonline.com). Further investigations are warranted to 
Table 1. Comparison in the Experimental Conditions Between the Current Study and Previous Studies

\begin{tabular}{|c|c|c|c|c|c|}
\hline \multicolumn{2}{|c|}{ Similarities } & \multicolumn{4}{|c|}{ Differences } \\
\hline \multicolumn{2}{|c|}{ Loading protocol } & & Current study & Previous study & References \\
\hline Nature & Unconfined & Species & Human & Rabbit or goat & $11,15,19,41$ \\
\hline Frequency & $1 \mathrm{~Hz}$ & Matrix system & Collagen & Agarose & 11,15 \\
\hline Magnitude & $10-15 \%$ & Loading duration & $1 \mathrm{~h} /$ day & 4 hours or $20 \mathrm{~min} /$ day & $11,15,19$ \\
\hline
\end{tabular}

find out the significance of such alignment response in hMSCs and whether the same alignment response is found in other cell types.

\section{Effects of compressive loading on MSC differentiation}

Previous studies reported the effects of compressive loading on chondrogenic differentiation of MSCs with and without supplementation of transforming growth factorbeta, ${ }^{11,15,17-19,39-41}$ which is a well-known biological factor inducing chondrogenic differentiation. Among some of these studies, cyclic compression without transforming growth factor-beta stimulated the production of GAGs, an extracellular matrix marker for chondrogenic differentiation, comparing with the unloaded controls. ${ }^{11,15,19}$ In the current study, no significant increase in GAGs has been noted in the loaded groups. In-house data on other intra- and extracellular markers for chondrogenic differentiation including sox-9 and type II collagen (Supplemental Figs. S2 and S3, respectively) also confirmed the results. Given a number of comparable parameters such as unconfined compression with same frequency of loading $(1 \mathrm{~Hz})$ and similar magnitude of loading (10-15\%), the discrepancy in results on chondrogenic differentiation may be due to other differences in culture conditions and loading protocols between the current and the previous studies (Table 1). First, the 3D matrix used to embed the rabbits MSCs in these studies was $4 \%$ agarose. Agarose is normally not interactive with cells, but the matrix system used in the current study is collagen, which usually interacts specifically with hMSCs via cell-matrix molecules such as integrin. $^{98}$ Second, the species from which the MSCs were isolated was different. Specifically, rabbit MSCs have been used in previous studies, ${ }^{11,15,19}$ while hMSC s were used in this study. Third, the duration of loading varied among different studies. For instance, in some studies, ${ }^{11,15}$ cyclic compression of 4 hours per day for 3,7 , and 14 consecutive days was applied, while in other, $10 \mathrm{~min}$ of loading was applied twice a day for 3, 5, and 7 consecutive days. ${ }^{19}$ In this study, compression of 1 hour per day for 7 consecutive days was used. This suggests that factors in relation to cell, matrix, and loading regime are all important factors affecting the effects of mechanical loading on MSC differentiation.

\section{Future directions}

It is important to investigate the status of differentiation of the compressively loaded hMSCs in detail although the collective evidence so far suggested that hMSCs are unlikely to differentiate toward chondrogenic (Fig. 10 and Supplemental Figs. 2 and 3) and osteogenic (Supplemental Fig. 4) lineages. Expression of differentiation markers in gene level using realtime polymerase chain reaction can be used to study the early onset of differentiation. Moreover, it is also important to investigate the multiple differentiating potential of the aligned hMSCs after compressive loading by supplementing wellknown chemical induction medium to the constructs ${ }^{99-101}$ so as to explore the significance of cell alignment in modulating the functional properties of tissue constructs. In addition, transmission of external forces to cells embedded in a matrix is dependent on the matrix stiffness. ${ }^{102}$ The assembly of cytoskeleton of cells with fibronectin on cell surface was also associated with the stiffness of the matrix. In particular, bundles of actin microfilaments and fibronectin were well defined in cells embedded in collagen gel anchored to the rigid substratum of a culture dish, while no bundles of actin microfilaments and fibronectin could be found in free-floating collagen gel, ${ }^{103}$ similar to what has been observed in the current study. As a result, how the embedded cells perceive the stiffness of their matrix microenvironment does affect their interaction with the extracellular matrix and hence the forces they experience via these cell-matrix interactions. It is therefore of our interest to study the effects of matrix stiffness on the cellular responses to mechanical loading so as to further understand the matrix-mediated force transmission in cells embedded in 3D constructs.

\section{Conclusion}

A simple, affordable, and high-throughput mechanical loading system based on modifications of existing laboratory setup has been developed to deliver controlled compressive loading to 3D tissue-engineered constructs. hMSCs embedded in collagen gel consisting of fibrous meshwork have been demonstrated to respond to both static and cyclic compression by reorienting themselves in an alignment parallel to the direction of loading in contrast to the absence of such alignment in unloaded controls. Nevertheless, the collagen fiber meshwork entrapping the hMSCs remained randomly distributed as it was and no sign of enhanced cellular metabolism and increased GAG production was noted, suggesting that hMSCs do not actively remodel the matrix meshwork upon compressive loading alone. This study presents an experimental model for mechanoregulation studies and can be used in screening and optimizing parameters during scaffold and loading regime design.

\section{Acknowledgments}

This work was supported by grants from AOSpine (AOSBRC-07-06), Innovation and Technology Commission, the Hong Kong Government (ITS/133/08), University Research Committee, the University of Hong Kong (11159180), and the University Strategic Research Theme on 
Nanobiotechnology. We thank Ms. Chow Mei Kwan for her help in the development of the program for FFT image analysis.

\section{Disclosure Statement}

No competing financial interests exist.

\section{References}

1. Estes, B.T., Gimble, J.M., and Guilak, F. Mechanical signals as regulators of stem cell fate. Curr Top Dev Biol 60, 91, 2004.

2. Elder, S.H., Kimura, J.H., Soslowsky, L.J., Lavagnino, M., and Goldstein, S.A. Effect of compressive loading on chondrocyte differentiation in agarose cultures of chick limb-bud cells. J Orthop Res 18, 78, 2000.

3. Elder, S.H., Goldstein, S.A., Kimura, J.H., Soslowsky, L.J., and Spengler, D.M. Chondrocyte differentiation is modulated by frequency and duration of cyclic compressive loading. Ann Biomed Eng 29, 476, 2001.

4. Thomas, G.P., and el Haj, A.J. Bone marrow stromal cells are load responsive in vitro. Calcif Tissue Int 58, 101, 1996.

5. Reich, K.M., and Frangos, J.A. Effect of flow on prostaglandin E2 and inositol trisphosphate levels in osteoblasts. Am J Physiol 261, C428, 1991.

6. Geiger, B., and Bershadsky, A. Exploring the neighborhood: adhesion-coupled cell mechanosensors. Cell 110, 139, 2002.

7. Girton, T.S., Barocas, V.H., and Tranquillo, R.T. Confined compression of a tissue-equivalent: collagen fibril and cell alignment in response to anisotropic strain. J Biomech Eng 124, 568, 2002.

8. Berry, C.C., Shelton, J.C., Bader, D.L., and Lee, D.A. Influence of external uniaxial cyclic strain on oriented fibroblast-seeded collagen gels. Tissue Eng 9, 613, 2003.

9. Wille, J.J., Elson, E.L., and Okamoto, R.J. Cellular and matrix mechanics of bioartificial tissues during continuous cyclic stretch. Ann Biomed Eng 34, 1678, 2006.

10. Pfeiler, T.W., Sumanasinghe, R.D., and Loboa, E.G. Finite element modeling of 3D human mesenchymal stem cellseeded collagen matrices exposed to tensile strain. I Biomech 41, 2289, 2008.

11. Huang, C.Y., Reuben, P.M., and Cheung, H.S. Temporal expression patterns and corresponding protein inductions of early responsive genes in rabbit bone marrow-derived mesenchymal stem cells under cyclic compressive loading. Stem Cells 23, 1113, 2005.

12. Mauck, R.L., Nicoll, S.B., Seyhan, S.L., Ateshian, G.A., and Hung, C.T. Synergistic action of growth factors and dynamic loading for articular cartilage tissue engineering. Tissue Eng 9, 597, 2003.

13. Lee, D.A., and Bader, D.L. Compressive strains at physiological frequencies influence the metabolism of chondrocytes seeded in agarose. J Orthop Res 15, 181, 1997.

14. Chowdhury, T.T., Bader, D.L., Shelton, J.C., and Lee, D.A. Temporal regulation of chondrocyte metabolism in agarose constructs subjected to dynamic compression. Arch Biochem Biophys 417, 105, 2003.

15. Huang, C.Y., Hagar, K.L., Frost, L.E., Sun, Y., and Cheung, H.S. Effects of cyclic compressive loading on chondrogenesis of rabbit bone-marrow derived mesenchymal stem cells. Stem Cells 22, 313, 2004.

16. Knight, M.M., Toyoda, T., Lee, D.A., and Bader, D.L. Mechanical compression and hydrostatic pressure induce reversible changes in actin cytoskeletal organisation in chondrocytes in agarose. J Biomech 39, 1547, 2006.

17. Mauck, R.L., Byers, B.A., Yuan, X., and Tuan, R.S. Regulation of cartilaginous ECM gene transcription by chondrocytes and MSCs in 3D culture in response to dynamic loading. Biomech Model Mechanobiol 6, 113, 2007.

18. Campbell, J.J., Lee, D.A., and Bader, D.L. Dynamic compressive strain influences chondrogenic gene expression in human mesenchymal stem cells. Biorheology 43, 455, 2006.

19. Park, S.H., Sim, W.Y., Park, S.W., Yang, S.S., Choi, B.H., Park, S.R., Park, K., and Min, B.H. An electromagnetic compressive force by cell exciter stimulates chondrogenic differentiation of bone marrow-derived mesenchymal stem cells. Tissue Eng 12, 3107, 2006.

20. Cassino, T.R., Anderson, R., Love, B.J., Huckle, W.R., Seamans, D.K., and Forsten-Williams, K. Design and application of an oscillatory compression device for cell constructs. Biotechnol Bioeng 98, 211, 2007.

21. Connelly, J.T., Garcia, A.J., and Levenston, M.E. Inhibition of in vitro chondrogenesis in RGD-modified threedimensional alginate gels. Biomaterials 28, 1071, 2007.

22. Huang, C.Y., Deitzer, M.A., and Cheung, H.S. Effects of fibrinolytic inhibitors on chondrogenesis of bone-marrow derived mesenchymal stem cells in fibrin gels. Biomech Model Mechanobiol 6, 5, 2007.

23. Burdick, J.A., and Vunjak-Novakovic, G. Review: engineered microenvironments for controlled stem cell differentiation. Tissue Eng Part A 15, 205, 2008.

24. Pittenger, M.F., Mackay, A.M., Beck, S.C., Jaiswal, R.K., Douglas, R., Mosca, J.D., Moorman, M.A., Simonetti, D.W., Craig, S., and Marshak, D.R. Multilineage potential of adult human mesenchymal stem cells. Science 284, 143, 1999.

25. Pittenger, M.F., and Martin, B.J. Mesenchymal stem cells and their potential as cardiac therapeutics. Circ Res 95, 9, 2004.

26. Le Blanc, K., Rasmusson, I., Sundberg, B., Gotherstrom, C., Hassan, M., Uzunel, M., and Ringden, O. Treatment of severe acute graft-versus-host disease with third party haploidentical mesenchymal stem cells. Lancet 363, 1439, 2004.

27. Jaiswal, N., Haynesworth, S.E., Caplan, A.I., and Bruder, S.P. Osteogenic differentiation of purified, cultureexpanded human mesenchymal stem cells in vitro. I Cell Biochem 64, 295, 1997.

28. Johnstone, B., Hering, T.M., Caplan, A.I., Goldberg, V.M., and Yoo, J.U. In vitro chondrogenesis of bone marrowderived mesenchymal progenitor cells. Exp Cell Res 238, 265, 1998.

29. Williams, C.G., Kim, T.K., Taboas, A., Malik, A., Manson, P., and Elisseeff, J. In vitro chondrogenesis of bone marrowderived mesenchymal stem cells in a photopolymerizing hydrogel. Tissue Eng 9, 679, 2003.

30. Maxson, S., and Burg, K.J. Conditioned media cause increases in select osteogenic and adipogenic differentiation markers in mesenchymal stem cell cultures. J Tissue Eng Regen Med 2, 147, 2008.

31. Friedl, G., Schmidt, H., Rehak, I., Kostner, G., Schauenstein, K., and Windhager, R. Undifferentiated human mesenchymal stem cells (hMSCs) are highly sensitive to mechanical strain: transcriptionally controlled early osteo-chondrogenic response in vitro. Osteoarthritis Cartilage 15, 1293, 2007.

32. Simmons, C.A., Matlis, S., Thornton, A.J., Chen, S., Wang, C.Y., and Mooney, D.J. Cyclic strain enhances matrix mineralization by adult human mesenchymal stem cells via 
the extracellular signal-regulated kinase (ERK1/2) signaling pathway. J Biomech 36, 1087, 2003.

33. Wiesmann, A., Buhring, H.J., Mentrup, C., and Wiesmann, H.P. Decreased CD90 expression in human mesenchymal stem cells by applying mechanical stimulation. Head Face Med 2, 8, 2006.

34. Jagodzinski, M., Drescher, M., Zeichen, J., Hankemeier, S., Krettek, C., Bosch, U., and van Griensven, M. Effects of cyclic longitudinal mechanical strain and dexamethasone on osteogenic differentiation of human bone marrow stromal cells. Eur Cell Mater 7, 35, 2004.

35. Farng, E., Urdaneta, A.R., Barba, D., Esmende, S., and McAllister, D.R. The effects of GDF-5 and uniaxial strain on mesenchymal stem cells in 3-D culture. Clin Orthop Relat Res 466, 1930, 2008.

36. Qi, M.C., Hu, J., Zou, S.J., Chen, H.Q., Zhou, H.X., and Han, L.C. Mechanical strain induces osteogenic differentiation: Cbfa1 and Ets-1 expression in stretched rat mesenchymal stem cells. Int J Oral Maxillofac Surg 37, 453, 2008.

37. Sikavitsas, V.I., Bancroft, G.N., Holtorf, H.L., Jansen, J.A., and Mikos, A.G. Mineralized matrix deposition by marrow stromal osteoblasts in 3D perfusion culture increases with increasing fluid shear forces. Proc Natl Acad Sci USA 100, 14683, 2003.

38. Kim, S.H., Choi, Y.R., Park, M.S., Shin, J.W., Park, K.D., Kim, S.J., and Lee, J.W. ERK $1 / 2$ activation in enhanced osteogenesis of human mesenchymal stem cells in poly(lactic-glycolic acid) by cyclic hydrostatic pressure. J Biomed Mater Res A 80, 826, 2007.

39. Angele, P., Schumann, D., Angele, M., Kinner, B., Englert, C., Hente, R., Fuchtmeier, B., Nerlich, M., Neumann, C., and Kujat, R. Cyclic, mechanical compression enhances chondrogenesis of mesenchymal progenitor cells in tissue engineering scaffolds. Biorheology 41, 335, 2004.

40. Mouw, J.K., Connelly, J.T., Wilson, C.G., Michael, K.E., and Levenston, M.E. Dynamic compression regulates the expression and synthesis of chondrocyte-specific matrix molecules in bone marrow stromal cells. Stem Cells 25, 655, 2007.

41. Terraciano, V., Hwang, N., Moroni, L., Park, H.B., Zhang, Z., Mizrahi, J., Seliktar, D., and Elisseeff, J. Differential response of adult and embryonic mesenchymal progenitor cells to mechanical compression in hydrogels. Stem Cells 25, 2730, 2007.

42. Schumann, D., Kujat, R., Zellner, J., Angele, M.K., Nerlich, M., Mayr, E., and Angele, P. Treatment of human mesenchymal stem cells with pulsed low intensity ultrasound enhances the chondrogenic phenotype in vitro. Biorheology 43, 431, 2006.

43. Cui, J.H., Park, K., Park, S.R., and Min, B.H. Effects of lowintensity ultrasound on chondrogenic differentiation of mesenchymal stem cells embedded in polyglycolic acid: an in vivo study. Tissue Eng 12, 75, 2006.

44. Klein-Nulend, J., Roelofsen, J., Sterck, J.G., Semeins, C.M., and Burger, E.H. Mechanical loading stimulates the release of transforming growth factor-beta activity by cultured mouse calvariae and periosteal cells. J Cell Physiol 163, 115, 1995.

45. Miyanishi, K., Trindade, M.C., Lindsey, D.P., Beaupre, G.S., Carter, D.R., Goodman, S.B., Schurman, D.J., and Smith, R.L. Dose- and time-dependent effects of cyclic hydrostatic pressure on transforming growth factor-beta3-induced chondrogenesis by adult human mesenchymal stem cells in vitro. Tissue Eng 12, 2253, 2006.
46. Chan, B.P., Hui, T.Y., Yeung, C.W., Li, J., Mo, I., and Chan, G.C. Self-assembled collagen-human mesenchymal stem cell microspheres for regenerative medicine. Biomaterials 28, 4652, 2007.

47. Cheng, H.W.T.K., Cheung, K.M.C., Chan, D., and Chan, B.P. Decellularization of chondrocyte-encapsulated collagen microspheres. World Forum for Spine Research-The Intervertebral disc First Japanese Meeting. The Westin Miyako Kyoto, Kyoto, Japan, 2008.

48. Wong, H.L., Wang, M.X., Cheung, P.T., Yao, K.M., and Chan, B.P. A 3D collagen microsphere culture system for GDNF-secreting HEK293 cells with enhanced protein productivity. Biomaterials 28, 5369, 2007.

49. Lee, M., Lo, A.C., Cheung, P.T., Wong, D., and Chan, B.P. Drug carrier systems based on collagen-alginate composite structures for improving the performance of GDNFsecreting HEK293 cells. Biomaterials 30, 1214, 2009.

50. Yeung, C.W.C.K., Chan, D., and Chan, B.P. A Novel 3-Dimensional Culture System for Mouse Embryonic Stem Cells. International Society for Stem Cell Research 5th Annual Meeting. Cairns, Queensland, Australia, 2007, p. 340.

51. Hui, T.Y., Cheung, K.M., Cheung, W.L., Chan, D., and Chan, B.P. In vitro chondrogenic differentiation of human mesenchymal stem cells in collagen microspheres: influence of cell seeding density and collagen concentration. Biomaterials 29, 3201, 2008.

52. Li, J., Law, H.K., Lau, Y.L., and Chan, G.C. Differential damage and recovery of human mesenchymal stem cells after exposure to chemotherapeutic agents. $\underline{\mathrm{Br} J \text { Haematol }}$ 127, 326, 2004.

53. Chaudhuri, S., Nguyen, H., Rangayyan, R.M., Walsh, S., and Frank, C.B. A Fourier domain directional filtering method for analysis of collagen alignment in ligaments. IEEE Trans Biomed Eng 34, 509, 1987.

54. $\mathrm{Ng}$, C.P., Hinz, B., and Swartz, M.A. Interstitial fluid flow induces myofibroblast differentiation and collagen alignment in vitro. J Cell Sci 118, 4731, 2005.

55. Barbosa, I., Garcia, S., Barbier-Chassefiere, V., Caruelle, J.P., Martelly, I., and Papy-Garcia, D. Improved and simple micro assay for sulfated glycosaminoglycans quantification in biological extracts and its use in skin and muscle tissue studies. Glycobiology 13, 647, 2003.

56. Jarman-Smith, M., Bodamyali, T., Stevens, C., Howell, J.A., Horrocks, M., and Chaudhuri, J.B. Human fibroblast culture on a crosslinked dermal porcine collagen matrix. Biochem Eng J 20, 217, 2004.

57. Croce, M.A., Silvestri, C., Guerra, D., Carnevali, E., Boraldi, F., Tiozzo, R., and Parma, B. Adhesion and proliferation of human dermal fibroblasts on collagen matrix. I Biomater Appl 18, 209, 2004.

58. Mosmann, T. Rapid colorimetric assay for cellular growth and survival: application to proliferation and cytotoxicity assays. J Immunol Methods 65, 55, 1983.

59. Chan, B.P., Li, C.H., Au-Yeung, K.L., Sze, K.Y., and Ngan, A.H. A microplate compression method for elastic modulus measurement of soft and viscoelastic collagen microspheres. Ann Biomed Eng 36, 1254, 2008.

60. Frank, C., Woo, S.L., Amiel, D., Harwood, F., Gomez, M., and Akeson, W. Medial collateral ligament healing. A multidisciplinary assessment in rabbits. Am J Sports Med 11, 379, 1983.

61. Frank, C., MacFarlane, B., Edwards, P., Rangayyan, R., Liu, Z.Q., Walsh, S., and Bray, R. A quantitative analysis of matrix alignment in ligament scars: a comparison of movement 
versus immobilization in an immature rabbit model. J Orthop Res 9, 219, 1991.

62. Canty, E.G., Starborg, T., Lu, Y., Humphries, S.M., Holmes, D.F., Meadows, R.S., Huffman, A., O'Toole, E.T., and Kadler, K.E. Actin filaments are required for fibripositormediated collagen fibril alignment in tendon. J Biol Chem 281, 38592, 2006.

63. Richardson, S.H., Starborg, T., Lu, Y., Humphries, S.M., Meadows, R.S., and Kadler, K.E. Tendon development requires regulation of cell condensation and cell shape via cadherin-11-mediated cell-cell junctions. Mol Cell Biol 27, 6218, 2007.

64. Cha, J.M., Park, S.N., Noh, S.H., and Suh, H. Timedependent modulation of alignment and differentiation of smooth muscle cells seeded on a porous substrate undergoing cyclic mechanical strain. Artif Organs 30, 250, 2006.

65. Hirschy, A., Schatzmann, F., Ehler, E., and Perriard, J.C. Establishment of cardiac cytoarchitecture in the developing mouse heart. Dev Biol 289, 430, 2006.

66. Wang, J.H., Jia, F., Gilbert, T.W., and Woo, S.L. Cell orientation determines the alignment of cell-produced collagenous matrix. J Biomech 36, 97, 2003.

67. Saffitz, J.E., Kanter, H.L., Green, K.G., Tolley, T.K., and Beyer, E.C. Tissue-specific determinants of anisotropic conduction velocity in canine atrial and ventricular myocardium. Circ Res 74, 1065, 1994.

68. Juncosa-Melvin, N., Boivin, G.P., Gooch, C., Galloway, M.T., West, J.R., Dunn, M.G., and Butler, D.L. The effect of autologous mesenchymal stem cells on the biomechanics and histology of gel-collagen sponge constructs used for rabbit patellar tendon repair. Tissue Eng 12, 369, 2006.

69. Juncosa-Melvin, N., Shearn, J.T., Boivin, G.P., Gooch, C., Galloway, M.T., West, J.R., Nirmalanandhan, V.S., Bradica, G., and Butler, D.L. Effects of mechanical stimulation on the biomechanics and histology of stem cell-collagen sponge constructs for rabbit patellar tendon repair. Tissue Eng 12, 2291, 2006.

70. Eastwood, M., Mudera, V.C., McGrouther, D.A., and Brown, R.A. Effect of precise mechanical loading on fibroblast populated collagen lattices: morphological changes. Cell Motil Cytoskeleton 40, 13, 1998.

71. Wille, J.J., Ambrosi, C.M., and Yin, F.C. Comparison of the effects of cyclic stretching and compression on endothelial cell morphological responses. J Biomech Eng 126, $545,2004$.

72. Kemkemer, R., Neidlinger-Wilke, C., Claes, L., and Gruler, $\mathrm{H}$. Cell orientation induced by extracellular signals. Cell Biochem Biophys 30, 167, 1999.

73. Neidlinger-Wilke, C., Grood, E.S., Wang, J.-C., Brand, R.A., and Claes, L. Cell alignment is induced by cyclic changes in cell length: studies of cells grown in cyclically stretched substrates. J Orthop Res 19, 286, 2001.

74. Neidlinger-Wilke, C., Grood, E., Claes, L., and Brand, R. Fibroblast orientation to stretch begins within three hours. J Orthop Res 20, 953, 2002.

75. Costa, K.D., Lee, E.J., and Holmes, J.W. Creating alignment and anisotropy in engineered heart tissue: role of boundary conditions in a model three-dimensional culture system. Tissue Eng 9, 567, 2003.

76. Takemasa, T., Yamaguchi, T., Yamamoto, Y., Sugimoto, K., and Yamashita, K. Oblique alignment of stress fibers in cells reduces the mechanical stress in cyclically deforming fields. Eur J Cell Biol 77, 91, 1998.
77. Wang, J.H., Goldschmidt-Clermont, P., Wille, J., and Yin, F.C. Specificity of endothelial cell reorientation in response to cyclic mechanical stretching. J Biomech 34, 1563, 2001.

78. Mudera, V.C., Pleass, R., Eastwood, M., Tarnuzzer, R., Schultz, G., Khaw, P., McGrouther, D.A., and Brown, R.A. Molecular responses of human dermal fibroblasts to dual cues: contact guidance and mechanical load. Cell Motil Cytoskeleton 45, 1, 2000.

79. Lee, E.J., Holmes, J.W., and Costa, K.D. Remodeling of engineered tissue anisotropy in response to altered loading conditions. Ann Biomed Eng 36, 1322, 2008.

80. Ng, C.P., and Swartz, M.A. Fibroblast alignment under interstitial fluid flow using a novel 3-D tissue culture model. Am J Physiol Heart Circ Physiol 284, H1771, 2003.

81. Loesberg, W.A., Walboomers, X.F., van Loon, J.J., and Jansen, J.A. The effect of combined cyclic mechanical stretching and microgrooved surface topography on the behavior of fibroblasts. J Biomed Mater Res A 75, 723, 2005.

82. Walboomers, X.F., Croes, H.J., Ginsel, L.A., and Jansen, J.A. Growth behavior of fibroblasts on microgrooved polystyrene. Biomaterials 19, 1861, 1998.

83. Wang, J.H., Yang, G., Li, Z., and Shen, W. Fibroblast responses to cyclic mechanical stretching depend on cell orientation to the stretching direction. I Biomech 37, 573, 2004.

84. Wang, J.H., and Grood, E.S. The strain magnitude and contact guidance determine orientation response of fibroblasts to cyclic substrate strains. Connect Tissue Res 41, 29, 2000

85. den Braber, E.T., de Ruijter, J.E., Smits, H.T., Ginsel, L.A., von Recum, A.F., and Jansen, J.A. Quantitative analysis of cell proliferation and orientation on substrata with uniform parallel surface micro-grooves. Biomaterials 17, 1093, 1996.

86. Manwaring, M.E., Walsh, J.F., and Tresco, P.A. Contact guidance induced organization of extracellular matrix. Biomaterials 25, 3631, 2004.

87. Su, W.T., Liao, Y.F., and Chu, I.M. Observation of fibroblast motility on a micro-grooved hydrophobic elastomer substrate with different geometric characteristics. Micron 38, 278, 2007.

88. Brunette, D.M. Fibroblasts on micromachined substrata orient hierarchically to grooves of different dimensions. Exp Cell Res 164, 11, 1986.

89. Houtchens, G.R., Foster, M.D., Desai, T.A., Morgan, E.F. and Wong, J.Y. Combined effects of microtopography and cyclic strain on vascular smooth muscle cell orientation. J Biomech 41, 762, 2008.

90. Clark, P., Connolly, P., Curtis, A.S., Dow, J.A., and Wilkinson, C.D. Cell guidance by ultrafine topography in vitro. J Cell Sci 99 (Pt 1), 73, 1991.

91. Clark, P., Connolly, P., and Moores, G.R. Cell guidance by micropatterned adhesiveness in vitro. J Cell Sci 103 (Pt 1), 287, 1992.

92. Corey, J.M., Lin, D.Y., Mycek, K.B., Chen, Q., Samuel, S., Feldman, E.L., and Martin, D.C. Aligned electrospun nanofibers specify the direction of dorsal root ganglia neurite growth. J Biomed Mater Res A 83, 636, 2007.

93. Chew, S.Y., Mi, R., Hoke, A., and Leong, K.W. The effect of the alignment of electrospun fibrous scaffolds on Schwann cell maturation. Biomaterials 29, 653, 2008.

94. Henshaw, D.R., Attia, E., Bhargava, M., and Hannafin, J.A. Canine ACL fibroblast integrin expression and cell alignment in response to cyclic tensile strain in three-dimensional collagen gels. J Orthop Res 24, 481, 2006. 
95. Altman, G.H., Horan, R.L., Martin, I., Farhadi, J., Stark, P.R., Volloch, V., Richmond, J.C., Vunjak-Novakovic, G., and Kaplan, D.L. Cell differentiation by mechanical stress. FASEB J 16, 270, 2002.

96. Khatiwala, C.B., Peyton, S.R., Metzke, M., and Putnam, A.J. The regulation of osteogenesis by ECM rigidity in MC3T3E1 cells requires MAPK activation. J Cell Physiol 211, 661, 2007.

97. Khatiwala, C.B., Peyton, S.R., and Putnam, A.J. Intrinsic mechanical properties of the extracellular matrix affect the behavior of pre-osteoblastic MC3T3-E1 cells. Am J Physiol Cell Physiol 290, C1640, 2006.

98. Salasznyk, R.M., Williams, W.A., Boskey, A., Batorsky, A., and Plopper, G.E. Adhesion to vitronectin and collagen I promotes osteogenic differentiation of human mesenchymal stem cells. J Biomed Biotechnol 2004, 24, 2004.

99. Tuli, R., Tuli, S., Nandi, S., Huang, X., Manner, P.A., Hozack, W.J., Danielson, K.G., Hall, D.J., and Tuan, R.S. Transforming growth factor-beta-mediated chondrogenesis of human mesenchymal progenitor cells involves $\mathrm{N}$ cadherin and mitogen-activated protein kinase and Wnt signaling cross-talk. J Biol Chem 278, 41227, 2003.

100. Watanabe, H., de Caestecker, M.P., and Yamada, Y. Transcriptional cross-talk between Smad, ERK1/2, and p38 mitogen-activated protein kinase pathways regulates transforming growth factor-beta-induced aggrecan gene expression in chondrogenic ATDC5 cells. J Biol Chem 276, 14466, 2001.
101. Barry, F., Boynton, R.E., Liu, B., and Murphy, J.M. Chondrogenic differentiation of mesenchymal stem cells from bone marrow: differentiation-dependent gene expression of matrix components. Exp Cell Res 268, 189, 2001.

102. Choquet, D., Felsenfeld, D.P., and Sheetz, M.P. Extracellular matrix rigidity causes strengthening of integrincytoskeleton linkages. Cell 88, 39, 1997.

103. Halliday, N.L., and Tomasek, J.J. Mechanical properties of the extracellular matrix influence fibronectin fibril assembly in vitro. Exp Cell Res 217, 109, 1995.

Address correspondence to: Barbara Pui Chan, Ph.D. Medical Engineering Program Department of Mechanical Engineering

The University of Hong Kong Room 711, Haking Wong Building Pokfulam Road

Hong Kong Special Administrative Region 852 China

E-mail: bpchan@hkucc.hku.hk

Received: December 30, 2008 Accepted: April 14, 2009

Online Publication Date: May 21, 2009 
